\title{
COLLOQUIA
}

\author{
Lech Miodyński \\ Instytut Filologii Słowiańskiej \\ Uniwersytet Adama Mickiewicza \\ Poznań
}

\section{Bogomil G'uzel Macedoński wirtuoz syntezy poetyckiej}

\begin{abstract}
$\mathrm{U}^{\mathrm{s}}$ rodzony w roku wybuchu II wojny światowej macedoński poeta Bogomil G’uzel od debiutu na początku lat sześćdziesiątych zajmował w swej ojczyźnie miejsce szczególne jako osobowość artystyczna odosobniona ze względu na wyjątkową rozległość swych ideowo-filozoficznych koneksji. Anglista z wykształcenia, tłumacz między innymi Szekspira, Audena, Eliota i Rilkego, uchodził w literaturze jugosłowiańskiej Macedonii - zyskującej dopiero międzynarodową rozpoznawalność - za autora hermetycznego, odróżnianego zwykle etykietą erudycyjnego neoklasycyzmu. Jednocześnie przez pół wieku twórczej drogi (której wiernie towarzyszyły uważne komentarze coraz młodszych zastępów literaturoznawców - od Georgi Staleva i Vlady Uroševicia, przez Lidiję Kapuševską-Drakulevską, do Sonji Stojmenskiej-Elzeser) niejednokrotnie odczytywano przesłanie jego wierszy w konstelacji „narodowej” - jako głosu podmiotu lirycznego czującego się spadkobiercą idei zbiorowej i autora wizjonerskich motywów losów południowosłowiańskiej społeczności w historii. Od początku niepowtarzalny w tej części byłej Jugosławii charakter jego dzieła sprowadzał się do dwóch nietypowych w tym środowisku czynników: estetycznego dialogu nawiązanego z europejską w dużej mierze zachodnią - tradycją literackich arcydzieł w jej pełnej rozciągłości oraz próby szerokiego ogarnięcia dziejów kilku cywilizacji przez intertekstualne echa dokonywanych lektur i ich uściślenia eseistyczne. Silne kontekstualne uwikłanie tej poezji, szukającej natchnienia w podobnych postawach Pounda czy Eliota, pozwala jej twórcy z szerokim zapasem tolerancji filozoficznej i religijnej ujmować świat w perspektywie w pełni sobie uświadamianych norm natury, rozumu i kultury, między innymi za pośrednictwem kategorii czasu, miejsca, słowa, Boga, mitu, egzystencji i wolności.
\end{abstract}


Będąc twórcą debiutującym kilka lat po przypadającym na okres 19541958 apogeum konfrontacji między zwolennikami poetyk realistycznej i spóźnionej awangardowej, nie był już obciążony zobowiązaniami rozrachunku z krótkotrwałym epizodem folklorystycznego (soc)realizmu, na gruzach którego poeci generacji tzw. trzeciej fali (Radovan Pavlovski, Petre M. Andreevski, Jovan Koteski, Vlada Uroševik', Petar Boškovski) zbudowali znacznie nowocześniejszy wzorzec liryczny, oparty na imażynistycznym, surrealistycznym czy neoklasycystycznym przetworzeniu materii macedońskiej tradycji ludowej oraz wysokoartystycznej. W przypadku Bogomila G’uzela - którego turecko brzmiące nazwisko okazuje się całkowicie mylnym tropem genealogicznym - inspiracje leżały pierwotnie w anglosaskiej kulturze literackiej, poznawanej przez jej uniwersyteckiego adepta podczas stypendiów w Edynburgu i później w Iowa City (gdzie poznał Audena) oraz podczas podróży do Stanów Zjednoczonych i Irlandii. W końcu lat siedemdziesiątych uczestniczył w prestiżowych międzynarodowych festiwalach poetyckich w Rotterdamie i San Francisco (tam występując w tercecie z noblistami - Miłoszem i Singerem), a i sam przez wiele lat stał jako organizacyjny spiritus movens na czele podobnego przedsięwzięcia w macedońskiej Strudze. Znany jest przede wszystkim jako poeta, ale wydał również zbiory esejów i prozy podróżopisarskiej oraz kilka dramatów. Pracował między innymi jako kierownik literacki skopijskiego Teatru Dramatycznego, pełnił też funkcję pierwszego przewodniczącego Związku Niezależnych Pisarzy Macedonii (od 1994). Dopiero po 1991 roku do szerszej opinii publicznej mogły dotrzeć tragiczne fakty z życiorysu ojca twórcy - znanego filozofa o sympatiach probułgarskich i jednocześnie prawicowych, dyrektora Radia Skopje w latach II wojny światowej. Jego wcześniejszy pobyt w serbskim więzieniu i egzekucja jako „wroga narodu” w 1945 roku z rąk władzy titowskiej przez wiele dziesięcioleci kładły się cieniem na nieoficjalnym wizerunku poety.

Cechami specyficznymi języka artystycznego G’uzela są syntetyczność, polifoniczność i intelektualizm - sprawiające, iż nieustanne przekraczanie granic formy gatunkowej, tematu i granic samego tekstu tworzy tu wiersz wielogłosowy, złożony z rozmaitych wątków kulturowych, filozoficznych i historycznych, konstruujących zarówno syntezę ponadczasowych pierwiastków literatury powszechnej, jak i przewrotną antyestetykę zwątpienia w sens uniwersalnego piękna. Zakorzenione w takiej postaci literackiego wyrazu słowa-klucze z wczesnych tekstów (kamień, koń, słońce, walka, poganin, równina, Arka czy Prometeusz) uzupełniane są nawiązaniami do obrazów poetyckich wypatrywanych u Blake'a, Pounda, Eliota, Yeatsa, Hölderlina, Rilkego, Audena, Ginsberga względnie Kavafisa, i włączane do lirycznej diagnozy dzisiejszej sytuacji egzystencjalnej podmiotu, jak i stojącego metaforycznie za jego monologiem narodu. W takiej właśnie perspektywie uwi- 
daczniają się problemy czy idee przewodnie kolejnych wydawanych tomów, a należą do nich na przykład: przemoc i ekspresja barbarzyńcy, rola mitu w świadomości etycznej, zagubienie w znaczeniach języka przyrody, fenomen czasu, związki natury z absolutem, balast codziennej rzeczywistości, kryzys komunikacji ze światem, wizja nowej przestrzeni poetyckiej i międzyludzkiej, nieustannie trwająca kosmogonia czy wiecznotrwała „narracja świata”.

Wbrew widocznym wysiłkom wkładanym przez liryczne „ja” G’uzela w zrozumienie absurdów współczesnej cywilizacji, z każdej linijki jego wiersza przenika do czytelnika poczucie głębokiego szacunku dla archaicznej i pierwotnej zarazem dawności, która miałaby podążać bez końca za całą ludzką wynalazczością ideologiczną, manifestując się dyskursywnie w koncepcjach „wiecznego teraz” i „żywiołowej przeszłości”. Ta niewyczerpana w narodowym dziedzictwie, dynamiczna zbiorowa potencja stanowiłaby istotę macedońskiego stylu życia religijnego i moralnego. Zgodnie z takim punktem widzenia słowiańscy Macedończycy, poddani w continuum swego „narodowego ducha” rygorowi negatywizmu, trwaliby bowiem w kulminacjach własnych dążeń społecznych i w postaciach zjawisk artystycznych poza nawiasem ewolucyjnego postępu w kulturze europejskiej - w stanie boskiego barbarzyństwa. Taki status rodzimego etnikum wynikałby, jak można wywnioskować z licznych u G’uzela eseistycznych podstaw poetyki sformułowanej, z charakterystycznego dlań ciągłego odszyfrowywania fatalnej sprzeczności pomiędzy wartościami konserwatywnymi i modernizującymi kod własnej kultury. Opozycją wobec psychologicznie i literacko atrakcyjnej mitycznej „przeszłości” jest tkwiąca w sztywnym pancerzu wieków „historia” - proces mechanicznie następujących po sobie zdarzeń, abstrakcyjnych form czasu pozostających dla tego narodu anonimowymi i obcymi z powodu pozbawienia go na stulecia podmiotowości politycznej. Tak widziany dualizm tradycji humanistycznej (którą wciąż trzeba w tym środowisku wzbogacać o elementy zewnętrzne - choćby antyczne, bizantyjskie czy, jak to czynił Pound, dalekowschodnie - by nie popaść w poczucie skrajnej izolacji) szczególną rangę nadaje doświadczeniu pra-bycia „tutaj”, elementarnemu déjà-vu o zabarwieniu etycznym:

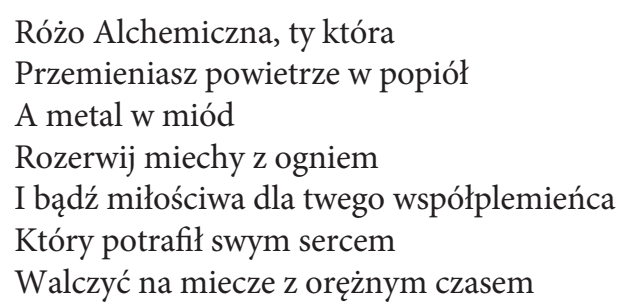

Różo Alchemiczna, ty która

Przemieniasz powietrze w popiół

A metal w miód

Rozerwij miechy z ogniem

I bądź miłościwa dla twego współplemieńca

Który potrafił swym sercem

Walczyć na miecze z orężnym czasem

Róża Alchemiczna [tłum. L.M.] ${ }^{1}$

1 Przekład fragmentów poezji Bogomila G’uzela podaję w tłumaczeniu własnym. 
Ów punkt wyjścia całej późniejszej poetyckiej tyrady G’uzela pozwala zrozumieć również jego szczegółowe poglądy filozoficzne, religijne oraz estetyczne: zamysł człowieka jako alegorii cywilizacji, symbolizujący syntagmę trwania układ obrazów bytu archaicznego (walka, pieśń, głód, kość, krew), sens paraleli „Adam - Macedonia” i koncepcję „niedochrzczenia” Macedończyków zwalniającą ich z odpowiedzialności za konsekwencje grzechu pierworodnego, panteistyczno-ortodoksyjny synkretyzm (już niemal ćwierć wieku temu w rozmowie $\mathrm{z}$ autorem tych słów poeta wyznał, że teologię prawosławną stosunkowo późno przybliżył mu dopiero „anglosaski” archimandryta Timothy Ware), nową estetykę „elementów-piktogramów” oraz kategorię eposu mającą wielkie symbole kulturowe sprowadzić na poziom interpretacji rzeczywistości codziennej, wzorzec współczesnego bohatera - „pytajnika metafizycznego”, widzenie rozumu destruującego wielkie legendy ludzkości, zapładniającą wyobraźnię funkcję (taoistycznej?) pustki otwierającej wierszowi szlak w przestrzeni wewnętrznej człowieka czy wreszcie słabość mechanizmów języka decydującą o silnej stronie palimpsestów liryki.

Oczom zagranicznego odbiorcy jawi się zatem talent literacki, który - dopiero z perspektywy kilkudziesięciu ostatnich lat obserwacji zjawisk artystycznych w tej części nieistniejącej już Jugosławii - uznać trzeba za niepowtarzalny. Będąc w swym kraju wespół z surrealistą Vladą Uroševiciem reprezentantem ożywczego kosmopolityzmu artystycznego w duchu neoawangardowym, utrzymał on honor korespondencji macedońskiej poezji z intelektualnie najwartościowszymi wzorcami światowymi, w czasach gdy albo próbowała ona wtórnie za nimi nadążać pod piórami twórców o mniejszej erudycji, albo trzymała się świętego kanonu metafor swej małej ojczyzny. Nie zamykając się ani na hermetyzm zachodnioeuropejskiej i amerykańskiej poezji czystej czy poetykę hieroglificzną, ani nie negując miejscowego substratu (greckiego antyku, bizantyjskiego decorum i dykcji folkloru), wykreowano tym samym wzorzec artyzmu syntezującego doświadczenia myślenia dialogowego w wizji „prądu uniwersalnego liryzmu”. Nie zapominając o fakcie skodyfikowania macedońskiego języka literackiego niecałe siedemdziesiąt lat temu - i o wieloletnich nie kończących się do 1991 roku dyskusjach na temat istoty rodzimości w literaturze, jej misjonarskiego powołania czy odzwierciedlania narodowej mitologii - warto więc podkreślić fakt, że już dwie dekady po zakończeniu wojny w kraju zaabsorbowanym polemikami o charakterze głównie lokalnym rozlegał się realnie przełamujący kompleks jednego $\mathrm{z}$ bałkańskich prowincjonalizmów „eliotowski” głos młodego poety: 
Jam jest czuwający w kielichu dniem i nocą kwitnącego hermafrodytycznego kwiatu - za którym słyszę jak płacze cała Hellada -

od kiedy przepadły dzień i noc

[...]

Oto sposób w jaki człowiek dostąpił

Nirwany

O Przebudzony lecz niemiły Sprawiedliwości.

Róża Alchemiczna [tłum. L.M.]

Książki opublikowane:

Poezja:

(1962) Медовина

(1963) Алхемска ружа

(1965) Мироноснищи

(1969) Одисеј и пеколот, (wybór)

(1972) Бунар во времето

(1977) Тркало на годината

(1980) Стварноста е се́

(1981) Опсада

(1982) Празен простор

(1986) Мрак и млеко

(1989) Рушејки го иидот

(1991) Одбрани песни, (wybór)

(1994) Гол живот

(1998) Хаос

(2000) Она

(2002) Одбрана поезија (1962-2002), (wybór)

(2010-2011) Избрани дела (wybór).

\section{Eseistyka:}

(1969) Историјата како маштеа

Proza:

(1975) Куќа цел свет

(1984) Легенди

\section{Dramaty:}

(1982) Мuто-стории

Anglojęzyczne tłumaczenia poezji Bogomila G’uzela:

(1973) Three, transl. by A.Krishana Lehrotra, Iowa City

(1981) Longing for the South. An Anthology of Contemporary Macedonian Poetry, ed.by S. Mahapatra, J.T. Boškovski, New Delhi 
(1999) Anthology of Contemporary Macedonian Poetry, ed. by I. Chashule, Th. Shapcott, Sydney

(2001) Wolf at the Door, transl. By P.H. Liotta, Riverside

Polskie translacje poezji Bogumila G’uzela:

(1982) „Literatura na Świecie”, nr 2

(1988) „Poezja”, nr 6

(2003) „Krasnogruda”, nr 16 